\title{
SWOT Analysis of a Ladyboy Cabaret Show Market in Phuket province, Thailand
}

\author{
Thirachaya Maneenetr \\ Director of Center for Asia-Pacific Tourism Research, \\ Faculty of Management Science, Khon Kaen University \\ Email: thirachaya@kku.ac.th \\ Thanh Ha Tran \\ Student in Master Degree of Tourism Management, Faculty of \\ Management Science, Khon Kaen University \\ Email:cholly.pen@gmail.com
}

\section{Doi:10.5901/mjss.2014.v5n23p653}

\section{Abstract}

The objective of this article is to evaluate the strengths, weaknesses, opportunities and threats for a Ladyboy Cabaret Show market in Phuket province, Thailand. The researchers applied the qualitative method to collect data from ten key informants. The results show that a Ladyboy Cabaret Show market is one of the entertainment markets which has enough potential to attract tourists. SWOT analysis identified ten strengths, eight weaknesses, ten opportunities and nine threats. Therefore, in order for a Ladyboy Cabaret Show market to be incorporated successfully in the entertainment market in Phuket province, promotion activities which enhance the awareness of tourists to ladyboys must be initiated. Also, creating souvenirs that depict Ladyboy Cabaret Shows, which put emphasis on ancillary services should be considered.

Keywords: strengths, weaknesses, opportunities and threats

\section{Introduction}

Tourism is one of the most important industries since it has the means to create employment, improve the infrastructure, generate revenues, and expand the economy (Akova \& Baynazoğlu, 2012; Boz et al., 2007). In Thailand, the direct contribution of travel and tourism to the GDP was $7.3 \%$ of the total GDP in 2013 and is forecast to rise by $6.8 \%$ between 2013 - 2023 in Thailand (World Travel \& Tourism Council, 2013). Therefore, the Thai government should emphasize the tourism industry as something to be included on the national agenda to drive the economic system.

Phuket province is located in southern Thailand, it is a famous tourism destination for domestic and international tourists. At present, The Phuket Provincial Administration Organization has issued policies to increase tourism and effectively implement a tourism development plan for Phuket. The provincial administration aims to promote Phuket as a world-class center of marine tourism, which could generate much revenue locally and nationally (Na Sakolnakorn et al., 2013).

In terms of tourism, Phuket province has a diversity of tourists' activities. The island's long history has shaped the Phuket of the present with its diverse ethnic groups, culture, architectural influence, and fine cuisine. These attributes have made Phuket a complete tourist destination that offers a lot more than its natural heritage of sea, sand, forest, and world-renowned diving sites. Sino-Portuguese architecture casts its spell delighting travelers to the city, while Phuket style hospitality has never failed to impress visitors from all walks of life (Tourism Authority of Thailand, n.d.). Additionally, the night life and entertainment activities are attractive factors to fascinate tourists, of which Ladyboy Cabaret Shows are prominent, featuring various performances of songs, dances, musicals and comedies which reflect a multi-culture from countries around the world such as China, India, Russia as so on. The clever choreography and fabulous costumes make the shows spectacular, colorful and fun. There seems to be a potential market in Phuket province.

In tourism destination management, it is very important to consider internal and external factors which affect tourists' activities to take advantage of strategic management of the destination (Goranczewski \& Puciato, 2010). Therefore, in this paper, the researchers investigated the strengths, weaknesses, opportunities and threats for a Ladyboy Cabaret show market in Phuket province, Thailand. 


\section{Objectives}

- To study the strengths, weaknesses, opportunities and threats for a Ladyboy Cabaret Show market in Phuket province, Thailand.

\section{Literature Review}

\subsection{Entertainment activities}

Increasingly it can be seen that living in "money rich, time poor" societies, the need for escapism from a long-hour working culture has stimulated the demand for new forms of entertainment and recreation (Smith, 2006). When travelling, entertainment and leisure activities are always top on the list of tourists (Adeboye, 2012). Entertainment refers to things that take place outside their home which 'entertain' people. Again this can include things that they watch, e.g. a musical at a theatre, or things that they can actively take part in, e.g. bingo, youth theatre, dance troops, orchestras, bands, choirs, karaoke. In today's world, entertainment is defined as the more popular forms of the performing arts such as variety shows and cabaret shows including singers, comedians, magicians, and dancers as well as rock and pop concerts (Hughes, 2000) which produces a pleasurable and satisfying experience (Chen, 2012). In the economic domain, entertainment plays a role in diversifying revenue sources as well as directly increasing tourism revenue (Loi \& Pearce, 2012). That is the reason why entertainment plays an important role in the tourism development of a destination.

\subsection{SWOT analysis}

SWOT analysis is a commonly-used tool for analyzing the environment to attain both a systematic approach and support for a decision in a situation (Wheelen \& Hunger, 1995). It has often been used in fields of business and extended to that of natural resource management in order to assess a given decision, project or policy directive in a systematic manner (Schmoldt et al. 2001). In SWOT analysis, internal and external factors are grouped into four categories called SWOT groups: strengths, weaknesses, opportunities and threats. The purpose of applying SWOT to a strategic planning process is usually to develop and adopt a strategy resulting in a good fit between the internal and external factors (Kajanus et al., 2012). SWOT analysis is not a new tool in management but it has been developed to assess the status and prospects of businesses (Collins-Kreiner \& Wall, 2007) and used to extensively evaluate alternative strategies in order to determine the best one for a given business setting. (Sevkli et al., 2012).

\section{Research Methodology}

To meet research objectives, the researchers applied the qualitative method, as detailed below:

\subsection{Research area}

Phuket province is one of the southern provinces of Thailand. It is an island with beautiful landscapes. Phuket province has an international airport to make it available to international tourists. That is why nowadays, Phuket province is one of the more famous destinations for tourists who would like to enjoy beach activities and experience the night life. Ladyboy Cabaret Shows are exciting activities to attract international tourists with their wonderful shows. Popular theaters now are Phuket Simon Cabaret, Simon Star Cabaret Show, and Aphrodite Cabaret Show.

\subsection{Participants}

The key informants included ten participants. They were ladyboy dancers, members of involved government organizations, and tourism entrepreneurs who are involved with ladyboy cabaret shows in Phuket province.

\subsection{Tool}

Semi-structured interviews were applied to collect data from the key informants which included important aspects related to the tourism market and Ladyboy Cabaret Shows in Phuket. Content analysis was used to identify data elements and a matrix table was used to analyze the qualitative data. 


\section{Result}

\subsection{Current situation of a Ladyboy Cabaret Show market in Phuket, Thailand}

Phuket province has a lot of theaters with Ladyboy Cabaret Shows such as Paradise Complex Patong, Simon Star Cabaret Show, Aphrodite Cabaret Show and especially Phuket Simon Cabaret Show which is prominent and widely wellknown. The cabaret shows comprise various performances with singing, dances, musicals and comedies which reflect a multi-culture from countries around the world such as China, India, Russia as so on. The clever choreography and fabulous costumes make the shows spectacular, colorful and fun. Moreover, Ladyboy Cabaret Shows are not sex shows; these shows accept a wide range of audiences from children to elderly persons. Therefore, Ladyboy Cabaret Shows are entertainment activities for the entire family. too.

Apart from the splendid performances, ladyboys play an important role in the shows but they are not tourism products. Their ability and creativity are core to the success of the shows. With regard to ladyboys, they are fully integrated in and accepted by Thai society; even those do not work in cabaret shows or performances. Ladyboy Cabaret Shows should be considered as an environment in which ladyboys can display their abilities and have equality in society.

Nowadays, the Ladyboy Cabaret Show market has a wide range of channels to reach international tourists. The official websites are in English and other foreign languages as well. These shows also are guaranteed by reviewers on Trip Advisors or other tourism websites. Tourists have several channels to make reservations for tickets such as by direct contacts, travel agency or reservations online with affordable and fair pricing.

\subsection{SWOT of a Ladyboy Cabaret Show market in Phuket, Thailand}

Table 1 shows SWOT of a Ladyboy Cabaret Show market in Phuket, Thailand

\begin{tabular}{|c|c|}
\hline Strengths & Weaknesses \\
\hline $\begin{array}{l}\text { 1. Diverse and wonderful performances } \\
\text { 2. Performances reflect a multi-culture from countries around the word } \\
\text { 3. Elaborate stage decorations } \\
\text { 4. Several channels to find out information about the shows } \\
\text { 5. Warm and hospitable service } \\
\text { 6. Ability of Ladyboys in dance and in entertaining } \\
\text { 7. Lots of theaters for Ladyboy Cabaret shows } \\
\text { 8. Ladyboy Cabaret Shows are appropriate for families with children } \\
\text { 9. A wide range of tour agencies } \\
\text { 10. Nightlife is attractive to tourists in the downtown area }\end{array}$ & $\begin{array}{l}\text { 1. Lack of visitor management } \\
\text { 2. Lack of activities for interaction between tourists and } \\
\text { Ladyboys } \\
\text { 3. Ticket prices for shows are too expensive } \\
\text { 4. Lack of activities to promote Ladyboy Cabaret Shows } \\
\text { 5. Lack of attractive souvenirs of Ladyboy Cabaret Shows } \\
\text { 6. Problems with the system for ticket reservations } \\
\text { 7. Lack of ancillary services for tourism during the shows } \\
\text { 8. Lack of collection of the feedback of tourists }\end{array}$ \\
\hline Opportunities & Threats \\
\hline $\begin{array}{l}\text { 1. Phuket is a center of trade and tourism in southern of Thailand } \\
\text { 2. Phuket Provincial Administration Organization has issued policies to } \\
\text { increase tourism and effectively implement a tourism development plan for } \\
\text { Phuket } \\
\text { 3. Development tourism is a key factor in development of the local } \\
\text { economy and the local community's quality of life } \\
\text { 4. Phuket International Airport is convenient for tourists travelling there } \\
\text { 5. Dissemination of a positive image of Phuket province as a world-class } \\
\text { center of marine tourism } \\
\text { 6. Diversity of tourists' activities such as MICE, Spa and Medical Tourism } \\
\text { 7. A paradise of international shopping } \\
\text { 8. Phuket province has the potential to promote tourism and trade } \\
\text { 9. Ability of staff in the tourism industry in speaking foreign languages } \\
\text { 10. Tourists' activities and festivals throughout the year }\end{array}$ & $\begin{array}{l}\text { 1. Prolonged political conflicts } \\
\text { 2. Unresolved environmental problems } \\
\text { 3. Security problems } \\
\text { 4. Environmental and natural resources conservation } \\
\text { 5. Waste management } \\
\text { 6. Transportation system and traffic jams } \\
\text { 7. High cost of living } \\
\text { 8. Natural disasters } \\
\text { 9. Competitive tourism markets in nearby regions }\end{array}$ \\
\hline
\end{tabular}

\section{Conclusion}

This study aims to investigate the strengths, weaknesses, opportunities and threats for a Ladyboy Carbaret Shows market in Phuket province, Thailand. The researchers conducted interviews with ten key participants to collect data about the current situation of Ladyboy Cabaret Shows and analyzed internal and external factors for a Ladyboy Cabaret Show 
market. SWOT analysis pointed out that a Ladyboy Cabaret Show market has ten strengths, eight weaknesses, ten opportunities and nine threats. The results led us to conclude that a Ladyboy Cabaret Show market can be one of the entertainment markets of the tourism industry in Phuket province. It has enough potential to attract tourists; especially international tourists who are excited about the amazing and harmonious performances. Apart from that, support from local government policy on tourism and the advantageous location of Phuket province are great opportunities for the development of a Ladyboy Cabaret Show market, particularly in the entertainment industry in Phuket.

However, a Ladyboy Cabaret Show market has a number of weaknesses in management of activities for interaction between tourists and ladyboys, ticket reservation systems, and souvenirs. Therefore, promoting activities to enhance the awareness of tourists about ladyboys, creating souvenirs that depict the Ladyboy Cabaret Shows, and emphasizing ancillary services should be considered to achieve success in the Ladyboy Cabaret Show entertainment market, in Phuket province.

\section{References}

Akova, O. \& Baynazoğlu, M.E. (2012). Congress Tourism in Turkey: SWOT Analysis and Related Strategies. International Conference on Eurasian Economies11-13 October 2012 - Almaty, Kazakhstan, pp 359 - 365.

Adeboye, C.A. (2012). The Impact of Entertainment on Tourism. Case study: Agency Remarc in Greece. Central Ostrobothnia University of Applied. Retrieved from http://www.theseus.fi/bitstream/handle/10024/47217/Adeboye_Christopher.pdf?sequence=1.

Boz, M., Ozkul, E., Aydin, S. (2007). SWOT analysis for the determining touristic policy and plans in Canakkale. In Bart Bonanie (Ed). Proceeding of the 2007 International Tourism Biennial, pp 61 -66. Canakkale Onsekiz Mart University.

Chen, C. (2012). Hierarchical linear relationship between the U.S. leisure and entertainment consumption. Technology in Society, 34(1), 44-54.

Collins-Kreiner, N. \& Wall, G. (2007). Evaluating tourism potential: A SWOT analysis of the Western Negev, Israel. Tourism Review, 55(1), $51-63$.

Goranczewski, B. \& Puciato, D. (2010). SWOT Analysis in the Formulation of Tourism Development Strategies for Destination. Tourism, 20 (2), 45 - 53. Retrieved from http://dspace.uni.lodz.pl:8080/xmlui/bitstream/handle/11089/1462/03_Goranczewski_ Puciato_2010_SWOT\%20ANALYSIS\%20IN\%20THE\%20FORMULATION\%20OF\%20TOURISM\%20DEVELOPMENT\%20STRA TEGIES\%20FOR\%20DESTINATIONS.pdf?sequence=1.

Hughes, H. (2000). Arts, Entertainment and tourism. Oxford: Butterworth Heinemann.

Kajanus, M., Leskinen, P., Kurttila, M. \& Kangas, J. (2012). Making use of MCDS methods in SWOT analysis-Lessons learnt in strategic natural resources management. Forest Policy and Economics, 20, 1-9.

Loi, K. \& Pearce, P.L. (2012). Powerful stakeholders' view of entertainment in Macao's future. Journal of Business Research, 65(1), 412.

Na Sakolnakorn, T.P., Naipinit, A. \& Kroeksakul, P. (2013). Sustainable Tourism Development and Management in the Phuket Province, Thailand.Asian Social Science, 9(7), 75-84.

Schmoldt, D., Kangas,J., Mendoza, G. \& Pesonen, M. (2001). The analytic hierarchy process in natural resource and environmental decision making. The Netherlands: Springer.

Sevkli, M., Oztekin, A.,Uysal, O., Torlak, G.,Turkyilmaz, A.,Delen, D. (2012). Development of a fuzzy ANP based SWOT analysis for the airline industry in Turkey. Expert Systems with Applications, 31(1), 14 - 24.

Smith, M. (2006). Entertainment and new leisure tourism. In D. Buhalis \& C. Costa (Eds). Tourism Business Frontiers: Consumers, products and industry. pp 220 - 227. Oxford, Burlington: Butterworth-Heinemann.

Tourism Authority of Thailand. (n.d.). Phuket. Retrieved from http://www.tourismthailand.org/Phuket.

Wheelen, T.L. \& Hunger, J.D. (1995). Strategic Management and Business Policy. Upper Saddle River, N.J: Prentice Hall.

World Travel \& Tourism Council. (2013). Travel\& Tourism: Economic Impact 2013, Thailand. Retrieved from http://www.wttc.org/site_ media/uploads/downloads/thailand2013.pdf. 